\title{
Social and Emotional Learning in a Freshman Seminar
}

\author{
Jeannette B. Wyatt ${ }^{1} \&$ Geraldine A. Bloemker ${ }^{2}$ \\ ${ }^{1}$ Center for Social Work Education, Widener University, Chester, PA, USA \\ ${ }^{2}$ School of Education, Innovation, and Continuing Studies, Widener University, Chester, PA, USA \\ Correspondence: Jeannette Wyatt, Center for Social Work Education, One University Place, Chester, PA 19013, \\ USA. Tel: 610-499-1285. E-mail: Jbwyatt@widener.edu
}

Received: November 18, 2012 Accepted: December 20, 2012 Online Published: January 25, 2013

doi:10.5539/hes.v3n1p106 URL: http://dx.doi.org/10.5539/hes.v3n1p106

\begin{abstract}
First year college students are challenged both socially and academically in their transition to college life. The literature suggests that social and emotional competence skills can help with this transition. This article describes the course content for a University freshman seminar that teaches skills in social and emotional competence in order to ease the transition into college and facilitate academic success. This paper discusses instruction about five core components of social and emotional competence: knowledge of emotions in self and others; self-management, relationship, and tolerance skills; and behavioral and perceptual flexibility. Specific content, assignments, and pedagogical techniques are discussed and implications for helping freshman are considered.
\end{abstract}

Keywords: social and emotional competence, freshman, college transition, academic success, skill building, retention, pedagogy

\section{Introduction}

This paper will discuss the infusion of social and emotional competence education into a first-year seminar at a metropolitan university. The reasons that universities offer these seminars vary, yet there is an overarching desire to help new students transition successfully to academic and campus life. In addition, colleges and universities are consistently looking for ways to increase the retention of students. The addition of social and emotional competence content can further facilitate the attainment of these goals as the skills involved are analogous to those required for the academic and personal success of college students.

\section{Literature Review}

\subsection{Freshman Seminars}

The implementation of first year seminars has been documented in the literature. Colleges and universities place their individual brands on first-year experience seminars. In a study done by Porter and Swing (2006) of 61 selected institutions, the seminars were coded into five formats. The formats ranged from courses that focused solely on the transition from high school to college and first semester success, to discipline specific courses administered by academic departments. These formats closely reflect the earlier work of Barefoot and Fidler (1992) that identified five types of seminars based upon information obtained from a survey conducted through the National Resource Center for the Freshman Year Experience. They found that freshman seminars ranged from those that provided more comprehensive orientation, specific academic skills or topics, basic study skills, and discipline specific preparation. Tobolowsky and Associates' (2008) 2006 National Survey of First-Year Seminars found that the classes tend to be small and have varying formats, reminiscent of those found in the works of Barefoot and Fidler (1992), as well as Porter and Swing (2006).

The seminar described in this article has an emphasis on the successful transition from high school to college, including a focus on skills to increase student connectedness, GPA, and retention. Among the many reasons that these seminars are offered is to increase the retention rates of freshman. Barefoot (2002) aptly emphasized that increased retention is a consistent goal in higher education. Research has found that indeed, first-year seminars do increase persistence from freshman to sophomore year (Pascarella and Terenzini, 2005). Bean and Eaton's (2001) work on best practices for building strong retention programming supports first-year seminars as a way to help students integrate the social and academic aspects of their lives. They focus on the psychological theories of attitude-behavior theory, coping behavior theory, self-efficacy theory, and attribution theory as psychological 
processes that should guide retention programming. This first-year seminar's emphasis on teaching the skills and insight needed for increased emotional competence operationalizes the notion that a student's positive psychological processes contribute to academic and personal success in college. It further validates the relevance of the aforementioned theoretical constructs that inform retention efforts.

\subsection{Social and Emotional Competence}

Social and emotional learning (SEL) has received increased attention in educational settings. The Collaborative for Academic, Social, and Emotional Learning (CASEL) was established in the 1990s to provide "international leadership for researchers, educators, and policy makers to advance the science and practice of school-based social and emotional learning...from preschool through high school" (Zins et al., 2004: vii). Interest in SEL at the post-secondary educational level has emerged more recently, partly out of a concern regarding retention rates among entering freshmen (Parker et al., 2005), and partly out of speculation that improvements in social and emotional learning may enhance academic performance (Parker et al., 2004). Our belief is that the appropriate curriculum in such seminars can do both (Wang N., Wilhite, S., Wyatt, J., Young, T., Bloemker, G., \& Wilhite, E., 2012).

Empirical and theoretical advancements in conceptualizing SEL are rooted in the theory of emotional intelligence. Emotional intelligence has been explored in several disciplines including psychology, sociology, anthropology, and education. Despite significant empirical and theoretical advancements in conceptualizing and clarifying the construct, disagreement remains regarding a universal definition for emotional intelligence or how to best assess it (Bar-On, 2000; Brackett \& Mayer, 2003; Davies, Stankov, \& Roberts, 1998; Goleman 1995; 1998; Mayer \& Salovey, 1997; Mayer, Caruso \& Salovey, 2000; Salovey \& Mayer, 1990; Druskat, Sala, \& Mount, 2006). Research recognizes two main models of emotional intelligence that currently dominate the literature and are at the forefront of a rather heated and productive debate.

The first model posits a trait-based approach to emotional intelligence that encompasses emotional abilities, personality traits, and social abilities (the BarOn Emotional Quotient Inventory [Bar-On EQi], Bar-On, 2002). Under this model, emotional intelligence is best defined as an array of non-cognitive capabilities, competencies, and skills that influence one's ability to succeed in coping with environmental demands and pressures (Bar-On, 2002; Goleman, 1995, 1998). The second model promotes an ability-based model and focuses on emotional abilities that are distinct from personality traits, and is more consistent with traditional models of cognitive ability than the trait-based model (the Mayer-Salovey-Caruso Emotional Intelligence Test [MSCEIT], Mayer, Salovey, \& Caruso, 2002). Under this model, emotional intelligence is defined as the capacity to reason about emotions and the capacity of emotion to enhance thought (Davies, Stankov, \& Roberts, 1998; Mayer \& Salovey, 1997; Salovey \& Mayer, 1990).

Despite their conceptual differences, both models have been linked to numerous positive and adaptive personal and social behaviors across a wide range of environmental contexts and occupations. For example, emotional intelligence has been positively correlated to empathic perspective-taking, self-monitoring in social situations, social skills, interpersonal sensitivity, pro-social tendencies, emotional stability, impulse control, adaptive defense styles, resilience, and the absence of psychopathology (e.g., Borek, 2006; Cavallo \& Brienza, 2002; Gertis, Derksen, \& Verbruggen, 2004; Lam \& Kirby, 2002; Law, Wong, \& Song, 2004; Lopes, Salovey, Cote, \& Beers, 2005; Lopes, Salovey, \& Straus, 2003; Mack-Allen, 2005; Pellitteri, 2002; Sala, 2006). Although there has been a history of healthy debate on the topic, the current consensus is that many social and emotional skills can be developed, enhanced, and assessed in the course of an educational process (Salovey \& Sluyter, 1997; Schutte, et al., 1998; Higgs \& Dulewicz, 1999; Saarni, 1999; Bar-On \& Parker, 2000; Petrides \& Furnham, 2000; Matthews, Zeidner \& Roberts, 2002; Zeidner, Roberts \& Matthews, 2002; Dulewicz \& Higgs, 2004; Law, Wong \& Song, 2004).

Understood as a competence-based trait that can be developed and enhanced through education, the concept of social and emotional competence is an ongoing product of emotional development and social learning, both of which can take place in educational settings and contribute to academic achievement (Bar-On, 2006; Goleman, 2006).

SEL is generally conceptualized as the development of a set of social and emotional skills (Bar-On, 2006; Goleman, 2006). Although the inventory of specific skills varies across investigations, these skills typically include:

- awareness and understanding of emotions in one's self and in others,

- an ability to manage one's own emotions, 
- tolerance for differences in others' perspectives, values and cultures,

- flexibility in one's own interpersonal behavior, and

- an ability to take an active role in cultivating productive relationships with others.

Researchers have found that social and emotional skills support positive life outcomes, such as work success, stress tolerance, increased group productivity and team effectiveness, greater leadership skills, and overall well-being (e.g., Cherniss, 2000; Bar-On, Handley, \& Fund, 2006; Goleman, 2006; Lopes, Cote, \& Salovey, 2006).

\subsection{Social and Emotional Competence and Academic Success}

The research on emotional intelligence and students' positive transition from high school to college is promising. Emotional intelligence and academic success were examined as students transitioned from high school to university (Parker et al., 2004). The past two decades support a large body of literature on academic success in higher education, yet its link to emotional competence is a more recent area of study. The Bar-On EQi Short form (Bar-On, 2002) was employed to measure students on multiple dimensions associated with emotional intelligence. The dimensions measured are intrapersonal abilities, interpersonal abilities, adaptability, and stress management. The study correlated these variables with high school grade point average (GPA), and first semester university GPA. "Results of the present study suggest quite strongly that intrapersonal, adaptability, and stress management abilities are important factors in the successful transition from high school to university" (Parker et al., 2004).

Parker and colleagues (Parker et al., 2005) continued research on the connection between academic achievement and emotional intelligence in order to predict a successful transition from high school to university. The results of this study were consistent with those of 2004. Emotionally competent students were able to label their feelings to help them understand and guide behavior, use realistic and flexible coping strategies, and manage stressful situations in a productive manner. The transition from high school to university relies on these and other competencies. Whether it is the transition from living at home to dorm life, or the change from daily access to high school teachers to less access to university professors, emotional ability is a skill that needs to be factored into student success.

A growing body of empirical research indicates that higher levels of social and emotional skills are positively correlated with a variety of positive outcomes for academic performance and overall adjustment to higher education settings (Parker et al, 2005; Petrides, Fredrickson, \& Furnham, 2004). In another study, Schulman (1995) found that scores on a test of optimism were a better predictor of freshman year grades than were SAT scores or high school grades. Similarly, Swart (1996) found that college students who had significantly higher emotional competence scores also received better grades. Wang, et al. (2012) found that teaching social and emotional competence not only increases that competence in freshman; it also increases their academic performance as measured by GPA.

\subsection{The Widener Emotional Learning Survey}

The Widener Emotional Learning Survey (WELS) was developed by a group of faculty at Widener University (Wang et al., 2011). The WELS group uses the phrase social and emotional learning, instead of emotional intelligence, to reflect that those emotional skills, capacities, and abilities can be learned and cultivated over time. The WELS is a 62-item, self-report measure that assesses five factors of social and emotional learning. Similar to the factors described earlier, the WELS factors include: awareness and understanding of emotions in one's self and in others; an ability to manage one's own emotions; tolerance for differences in others' perspectives, values, and cultures; flexibility in one's own interpersonal behavior; and ability to take an active role in cultivating productive relationships with others (Wang, Young, Wilhite, \& Marczyk, 2011). The freshman seminar content presented here uses the WELS factors as key components in social and emotionally learning.

\subsection{Social and Emotional Competence in Higher Education}

Although it appears that social and emotional learning plays an important role in students' academic achievement, little attention has been given to research on the development of SEL curricula in higher education programs. It may be that attention to social and emotional learning in higher education has been delayed by the focus on academic competence, leaving little time to consider the influence of social and emotional competence in acquiring academic knowledge and skills (Goleman, 1995, 1998, 2006).

\section{Social and Emotional Competence in a Freshman Seminar}

The logic behind the course content presented here is based on knowledge we have accumulated about the 
freshman year experience. A substantial number of first-year students are not adequately prepared for the work load required in college. This, in combination with the relative lack of "studying structure" in college (compared to high school and home) results in many freshmen reporting difficulties with time management and study skills. Other freshmen report that they have difficulties managing homesickness and roommate relationships (if they are residential students) or making friends and dealing with personal difficulties. In addition, knowledge of college supports and how to access them is not readily retained past orientation such that most freshman benefit from a refresher as well as encouragement and rehearsal to utilize available services.

Certain challenges exist for almost all entering freshmen. A major one is that they must rely more on themselves or their fellow students (rather than their parents or siblings) for self management. In addition, the student body at Widener is often more diverse than was the case at their high schools, requiring the development of an ability to contend with a broader range of differences in values, beliefs and interpersonal styles. This becomes particularly important when students are assigned group projects as assignments and/or are cohabitating in the dorms with such diversity.

By developing course content that addresses both the development of academic competencies (such as study skills and time management) and social and emotional competencies (such as awareness of emotions in self and others, self-management and interpersonal relationship skills), we are addressing the student's total experience. In addition, skills in each of these areas are inherently related to each other. The difficulties in the social and emotional spheres can undermine skills in the academic sphere, so that addressing both in the same course curriculum strengthens both in ways that will enhance persistence. For example, self-management skills might be considered to provide the foundation for time management skills.

The goals of increased retention, student academic and personal success set the stage for the development of a social and emotional competence content that was then integrated into an existing freshman seminar course. The combination of academic success skills coupled with social and emotional competence skills seemed to be a natural progression is efforts to assist freshman with their transition into college.

\subsection{Objectives of This Freshman seminar}

- To assist students in the transition from home and high school to the higher education environment;

- To acquaint students with the social and emotional competencies associated with intra- and inter-personal success;

- To discuss opportunities for direct application of these competencies to both academic and personal life; and

- To help students acquire the social, emotional and academic skills and resources needed to be a successful college student.

\subsection{Course Content}

- time management;

- class participation and note-taking;

- knowledge of one's own emotions and awareness of the emotions of others;

- active learning;

- self-management - physical, emotional and behavioral;

- critical thinking;

- relationship skills;

- appreciating difference and tolerance for disagreement;

- test-taking - both written and oral;

- perspective-taking; and

- behavioral flexibility.

The social and emotional competence material was incorporated into three sections of an existing Freshman Seminar course. Specific attention to the skills outlined for social and emotional competence was infused with the focus on academic skill building. The same syllabus, readings, instructional materials, and exercises were implemented in each of the three sections. To maximize "instructional fidelity," guidelines were developed that pertain to the use of this course content so that the same experience was provided in each section. Instructors for the course met prior to teaching the class and during the semester to discuss the implementation of the curriculum, assess pedagogical techniques, and assess consistency between sections. 


\subsection{Teaching Methods, Techniques, and Materials}

Each instructor for this seminar implemented the same pedagogical methods for consistency and efficacy in teaching the skills. In addition, all of the instructors for this course had clinical training in the fields of social work and psychology, including work with adolescents. As such, they were skilled at facilitating the development of insight and assisting in problem-solving. We believe this orientation helped those instructors to be more attuned to the vulnerabilities of the developmental stage and the transition tasks at hand. These instructors were better able to assess challenges that students faced in the areas of social and emotional competence and how they led to barriers in the academic realm. This also led to smoother integration of social and emotional learning with academic skills. Specific pedagogical methods, techniques, and materials included:

- Lecture

- Discussion

- Experiential exercises including role plays and rehearsal

- Brainstorming and directed problem solving

- Directed reflection on experiences of observation

- Multi-media materials including music, movies, television

- Interaction with campus support personnel

- Team exercises to demonstrate concepts

- Small group work to develop insight and integrate material

- Process reflection throughout the course

The core elements of social and emotional competence were taught specifically using many of these methods and techniques. In addition, materials were shared between instructors. Instructors worked together to delineate how to teach these concepts and help students integrate them with both their academic skills and their negotiation of life experiences in their first college year. Specific issues to cover as related to the core factors of social and emotional competence were outlined and pedagogical techniques were developed and used by all instructors. Throughout the course, the use of individual assignments versus classroom work was negotiated with students, especially accounting for their feelings of safety in exploring such issues, the group dynamics, and the issue at hand. Students were always provided options for personal and private exploration and never forced to share too much for their own comfort.

\section{Social and Emotional Competence Factors}

Below is a description of each factor and the corresponding material covered.

\subsection{Knowledge of Emotions in Self and Others}

Students were educated about the variety of emotions we experience and instructed about the ways these emotions are displayed. In addition, students were engaged in discussions about emotional expression so they could identify them within social situations that were familiar. Specific case scenarios further assisted students in identifying both primary and secondary emotions, which led to knowledge about the use of emotions to protect oneself from further vulnerability. For example, in brainstorming about a peer who just experienced the break-up of a relationship, students identified the initial anger displayed but then were attuned to the underlying hurt and anxieties about loneliness, etc. By mirroring the experiences that students and their peers have had, these "case examples" helped students develop insight about themselves and become better attuned to perceiving emotional responses in others. Students also used contemporary music to identify emotions by analyzing song lyrics and brainstorming about what the writer was feeling, especially as these affective tones were reiterated in the corresponding music.

\subsection{Self Management Skills}

Students read material from a textbook and articles that discussed constructive and challenging behaviors of students. These included behaviors related to impulse control, focus and distraction, decision making skills, skills in delaying gratification, negotiating peer pressure and ultimately, connecting current behaviors to longer term goals. In addition, specific issues such as sexual behavior and drug and alcohol abuse were covered as well as general wellness instruction. In class exercises, students analyzed behavioral scenes from popular movies as well as their own experiences to assess the choices involved and the underlying influences on those choices. Students integrated their knowledge of emotions in this analysis and developed insight about the connections 
between regulating oneself and achieving prioritized goals. Students also brainstormed specifically about functional roles that supportive people have fulfilled for them, especially in the area of self management. They then brainstormed ways to meet those needs themselves or with new supports found at college. For instance, many students had parents at home who served at "taskmasters", "cheerleaders", and "nurturers". Students worked in small groups and used discussion as well as collages to depict how these roles could be fulfilled now, including their own increased use of self-management. Inherent in these explorations were relationship issues and this tied in directly with that course content.

\subsection{Relationship Skills}

Students discussed their current relationships and reflected on their use of relationships in their day to day management in journal assignments. Specifically explored in relationship skills were the negotiation of dependency and interdependency as well as specific roles. Students developed an increased awareness through reflection on how they asserted their needs in various relationships and used supports to assist themselves in the self management tasks described above. Communication styles and skills were directly reviewed and identified using movie clips and scenarios from students, especially as these tied in with getting needs met within a relationship. Identifying supports and exploring how to use them was covered as was the negotiation of one's own self awareness about vulnerabilities and the ability to trust others. Directly linked with relationship skills was the ability to tolerate difference in others.

\subsection{Tolerance Skills}

These skills were explored with students in both the smaller nuances of day to day relationships and in regard to larger issues of cultural diversity. Various experiential exercises, self reflection and analysis were used along with direct instruction about these skills. Students developed knowledge of their own styles and biases and how these differed from others. Students also linked tolerance skills with the other skills discussed above, including self-management, awareness of emotion, and relationship skills. Identifying areas of difference entailed the exploration of all of these factors as well as deep seated beliefs and lifestyle choices. Students also developed an awareness of differences they've adopted unconsciously through their upbringing and membership in certain groups. In addition to recognizing difference, students were taught about respecting difference and negotiating it within relationships. Ways to find common ground when necessary were explored through brainstorming sessions as well as direct instruction. These discussions were particularly rich since most students experienced a greater degree of diversity in all arenas now that they were away at college. Providing a safe context for them to explore their own beliefs and ways to negotiate difference constructively was pivotal and achieved via the group process and in individual assignments.

\subsection{Behavioral and Perceptive Flexibility}

This final area of instruction about social and emotional competence skills ties all of the areas together, as exercising behavioral and perceptive flexibility is reliant on skills in the other areas of functioning. These specific skills were explored across a variety of situations and relationships, which was particularly helpful in integrating them with the other social and emotional skills as well as academic skills. Within this area of instruction, students explored how they change across different situations, how their self-management changes in various relationships, and how their perception is affected in both. In addition, communication styles were linked to perceptive capabilities and students identified differences with the use of media as well as personal experience. Student's assumptions based on past experiences were analyzed as they affected variations in their reading of different situations and relationships. Case scenarios were used with specific factors changed across the analysis which resulted in greater insight by students about how their assumptions influenced their assessment. In addition, students were educated about barriers to their own flexibility as well as that of others including pride, shame, power, fear, and anxiety. Students learned about self reflection in the moment and harnessing their own willingness to change to better negotiate situations.

Assignments in the seminar aimed to increase the integration of material through direct application and reflection about concepts. Assignments included reading literature, writing reflection papers, analysis of material, directly applying concepts to real life experiences in papers and discussions, observation exercises, and a final paper in which students evaluated their social and emotional competence directly. Examples from life experiences were used to demonstrate concepts and help students apply them to their own experiences. Students openly discussed challenges they face in the transition to college and build their skills through discussion about how to apply concepts in their everyday life coupled with reflection about past experiences in overcoming obstacles. Students were taught to recognize how they have demonstrated these skills in the past and brainstorm about how they might use them differently in the future for better outcomes. This included an assessment of their current 
supports and the cultivation and use of new support in their college experience.

\section{Conclusion}

First year seminars have been correlated with increased retention and success rates for college students (Parker et al, 2005; Petrides, Fredrickson, \& Furnham, 2004). The enhanced academic skills, knowledge of available supports and how to use them, and supportive relationships established in the first year seminar aid the college student in their transition. Social and emotional competence has been linked to increased success in several realms of functioning, including academic achievement and management of situational stress. Functioning in social and emotional competence is also correlated to the academic and social skills necessary for a successful college transition. Thus, it was hypothesized that teaching students social and emotional competence within a first year freshman seminar further enhances their success and eases their transition into college. This article presented the inclusion of social and emotional competence skills into a freshman seminar and outlined techniques and methods used. The course content has been also been reported as effective in a research study by the authors and their colleagues (Wang N., et al, 2012).

\section{References}

Barefoot, B. O. (2000). The first-year experience: Are we making it any better? About Campus, 12-18.

Barefoot, B. O., \& Fidler, P. P. (1992). 1991 National Survey of Freshman Seminar Programming (Monograph No. 10). Columbia, SC: University of South Carolina, National Resource Center for The Freshman Year Experience.

Bar-On, R. (2000). Emotional and social intelligence: Insights from the emotional quotient inventory. In R. Bar-On \& J. D. A. Parker (Eds.), Handbook of emotional intelligence (pp. 363-388). San Francisco, CA: Jossey-Bass.

Bar-On, R. (2002). Bar-On Emotional Quotient Inventory: User's Manual. New York, NY: Multi-Health Systems, Inc.

Bar-On, R. (2006). The Bar-On model of emotional-social intelligence (ESI). Psicothema, 18(supl.), 13-25. Retrieved from the Consortium for Research on Emotional Intelligence in Organizations: www.eiconsortium.org

Bar-On, R., Handley, R., \& Fund, S. (2006). The impact of emotional intelligence on performance. In V. U. Druskat, F. Sala, \& G. Mount (Eds.), Linking emotional intelligence and performance at work: Current research evidence with individuals and groups (pp. 3-20). Mahway, NJ: Lawrence Erlbaum Associates.

Bar-On, R., \& Parker, J. D. A. (2000). Handbook of emotional intelligence. San Francisco, CA: Jossey-Bass.

Bean, J. P., \& Eaton, S. (2001). The psychology underlying successful retention practices. Journal of College Student Retention, 3(1), 73-89. http://dx.doi.org/10.1037/0022-3514.75.4.989

Borek, A. (2006). The relationship between emotional intelligence and personality factors in a graduate business school sample (Unpublished doctoral dissertation). Widener University, Chester, Pennsylvania.

Brackett, M. A., \& Mayer, J. D. (2003). Convergent, discriminant, and incremental validity of competing measures of emotional intelligence. Personality and Social Psychology Bulletin, 29(9), 1-12. (Reprinted from Emotional intelligence: Key readings on the Mayer and Salovey model, pp. 195-222, by P. Salovey, M. A. Brackett, \& J. D. Mayer, Eds., 2004, Port Chester: Dude)

Cavallo, K., \& Brienza, D. (2002). Emotional competence and leadership excellence at Johnson \& Johnson: The emotional intelligence and leadership study. Retrieved from http://www.eiconsortium.org/

Cherniss, C. (2000). Social and emotional competence in the workplace. In R. BarOn \& J. D. A. Parker (Eds.), Handbook of emotional intelligence (pp. 363-388). San Francisco, CA: Jossey-Bass.

Davies, M., Stankov, L., \& Roberts, R. (1998). Emotional intelligence: In search of an elusive construct. Journal of Personality and Social Psychology, 75(4), 989-1015. http://dx.doi.org/10.1037/0022-3514.75.4.989

Druskat, V. U., Sala, F., \& Mount, G. (2006). Linking emotional intelligence and performance at work: Current research evidence with individuals and groups. Mahway, NJ: Lawrence Erlbaum Associates.

Dulewicz, V., \& Higgs, M. (2004). Can emotional intelligence be developed? International Journal of Human Resource Management, 15(1), 95-111. http://dx.doi.org/10.1080/0958519032000157366

Gertis, L., Derksen, J. L., \& Verbruggen, A. B. (2004). Emotional intelligence and adaptive success of nurses caring for people with mental retardation and severe behavioral problems. Mental Retardation, 42(2), 
106-121. http://dx.doi.org/10.1352/0047-6765(2004)42<106:EIAASO >2.0.CO;2

Goleman, D. (1995). Emotional intelligence. New York: Bantam Books.

Goleman, D. (1998). Working with emotional intelligence. New York: Bantam Books.

Goleman, D. (2006). Social intelligence. New York: Bantam Books.

Higgs, M. J., \& Dulewicz, V. (1999). Making sense of emotional intelligence. Windsor: NFER-Nelson.

Lam, T. L., \& Kirby, S. L. (2002). Is emotional intelligence an advantage? An exploration of the impact of emotional and general intelligence on individual performance. The Journal of Social Psychology, 142(1), 133-143. http://dx.doi.org/10.1080/00224540209603891

Law, K. S., Wong, C. S., \& Song, L. (2004). The construct and criterion validity of emotional intelligence and its potential utility for management studies. Journal of Applied Psychology, 89(3), 483-496. http://dx.doi.org/10.1037/0021-9010.89.3.483

Lopes, P., Cote, S., \& Salovey, P. (2006). An ability model of emotional intelligence: Implications for assessment and training. In V. U. Druskat, F. Sala, \& G. Mount (Eds.), Linking emotional intelligence and performance at work: Current research evidence with individuals and groups (pp. 53-80). Mahway, NJ: Lawrence Erlbaum Associates.

Lopes, P. N., Salovey, P., Cote, S., \& Beers, M. (2005). Emotion regulation abilities and the quality of social interaction [Electronic version]. Emotion, 5(1), 113-118. http://dx.doi.org/10.1037/1528-3542.5.1.113

Lopes, P. N., Salovey, P., \& Straus, R. (2003). EI, personality, and the perceived quality of social relationships [Electronic version]. Personality and Individual Differences, 35, 641-658. http://dx.doi.org/10.1016/S0191-8869(02)00242-8

Mack-Allen, J. (2005). Relationship between emotional intelligence and personality factors in a community-based sample (Unpublished doctoral dissertation). Widener University, Chester, Pennsylvania.

Matthews, G., Zeidner, M., \& Roberts, R. (2002). Emotional intelligence: Science and myth. Cambridge, MA: MIT Press.

Mayer, J. D., Caruso, D., Salovey, P. (2000). Selecting a measure of emotional intelligence: the case of ability scales. In R. Bar-On \& J. D. A. Parker (Eds.), Handbook of emotional intelligence (pp. 320-342). San Francisco, CA: Jossey-Bass.

Mayer, J. D., \& Salovey, P. (1997). What is emotional intelligence? In P. Salovey \& D. Sluyter (Eds.), Emotional development and emotional Intelligence: Educational Implications (pp. 3-31). New York: Basic Books.

Mayer, J. D., Salovey, P., \& Caruso. D. R. (2002). Mayer-Salovey-Caruso Emotional Intelligence Test (MSCEIT) item booklet. Toronto, Ontario, Canada: Multi-Health Systems.

Parker, J. D. A., Summerfeldt, L. J., Hogan, M. J., \& Majeski, S. A. (2004). Emotional intelligence and academic success: Examining the transition from high school to university. Personality and Individual Differences, 36, 163-172. http://dx.doi.org/10.1016/S0191-8869(03)00076-X

Parker, J., Duffy, J., Wood, L., Bond, B., \& Hogan, M. (2005). Academic achievement and emotional intelligence: Predicting the successful transition from high school to university. Journal of the First-Year Experience, 17(1), 1-12.

Pascarella, E. T., \& Terenzini, P. T. (2005). How college affects students: Vol. 2. A third decade of research. San Francisco, CA: Jossey Bass.

Pellitteri, J. (2002). The relationship between emotional intelligence and ego defense mechanisms. The Journal of Psychology, 136(2), 182-194. http://dx.doi.org/10.1080/00223980209604149

Petrides, K. V., \& Furnham, A. (2000). On the dimensional structure of emotional intelligence. Personality and Individual Differences, 29, 313-320. http://dx.doi.org/10.1016/S0191-8869(99)00195-6

Petrides, K. V., Frederickson, N., \& Furnham, A. (2004). The role of trait emotional intelligence in academic performance and deviant behavior at school. Personality and Individual Differences, 36, 277-293. http://dx.doi.org/10.1016/S0191-8869(03)00084-9

Porter, S. R., \& Swing, R. L. (2006). Understanding how first-year seminars affect persistence. Research in Higher Education, 47(1), 89-108. http://dx.doi.org/10.1007/s11162-005-8153-6

Saarni, C. (1999). The development of emotional competence. New York: Guilford Press. 
Sala, F. (2006). The international business case: Emotional intelligence competencies and important business outcomes. In V. U. Druskat, F. Sala, \& G. Mount (Eds.), Linking emotional intelligence and performance at work: Current research evidence with individuals and groups (pp. 125-144). Mahway, NJ: Lawrence Erlbaum Associates.

Salovey, P., \& Mayer, J. D. (1990). Emotional intelligence. Imagination, Cognition, and Personality, 9, 185-211. http://dx.doi.org/10.2190/DUGG-P24E-52WK-6CDG

Salovey, P., \& Sluyter, D. J. (1997). Emotional development and emotional intelligence: Educational implications. New York: Basic Books.

Schulman, P. (1995). Explanatory style and achievement in school and work. In G. Buchanan \& M. Seligman (Eds.), Explanatory style. Hillsdale, NJ: Lawrence Erlbaum.

Schutte, N. S., Malouff, J. M., Hall, L. E., Haggerty, D. J., Cooper, J. T., Golden, C. J., \& Dornheim, L. (1998). Development and validation of a measure of emotional intelligence. Personality and Individual Differences, 25, 167-177. http://dx.doi.org/10.1016/S0191-8869(98)00001-4

Swart, A. (1996). The relationship between well-being and academic performance (Unpublished master's thesis). University of Pretoria, South Africa.

Tobolowsky, B. F. (2008). Summary of Selected Findings. In B. F. Tobolowsky \& Associates, 2006 National Survey of First-Year Seminars: Continuing innovations in the collegiate curriculum (Monograph. 51, pp. 97-102). Columbia, SC: University of South Carolina, National Resource Center for the First-Year Experience and Students in Transition.

Tobolowsky, B. F., \& Associates. (2008). 2006 National Survey of First-Year Seminars: Continuing innovations in the collegiate curriculum (Monograph No. 51). Columbia, SC: University of South Carolina, National Resource Center for the First-Year Experience and Students in Transition.

Wang, N., Young, T., Wilhite, S., \& Marczyk, G. (2011). Assessing students' emotional competence in higher education: Development and validation of the Widener Emotional Learning Scale. Journal of Psychoeducational Assessment, 20(10), 1-16.

Wang, N., Wilhite, S., Wyatt, J., Young, T., Bloemker, G., \& Wilhite, E. (2012). Impact of a college freshman social and emotional learning curriculum on student learning outcomes: An exploratory study. Journal of University Teaching \& Learning Practice. 9(2), 1-20.

Zeidner, M., Roberts, R. D., \& Matthews, G. (2002). Can emotional intelligence be schooled? A critical review. Educational Psychologist, 37(4), 215-231. http://dx.doi.org/10.1207/S15326985EP3704_2

Zins, J. E., Weissberg, R. P., Wang, M. C., \& Walberg, H. J. (Eds.). (2004). Building academic success on social and emotional learning: What does the research say? New York: Teachers College Press.

Note

Note 1. The curriculum presented in this article was described briefly in a paper by the authors and their colleagues which presented the findings of a research study using the curriculum. 